\title{
From the curve of the snake, and the scene of the crocodile: musings on learning and losing space, place and body
}

Susanne Gannon, University of Western Sydney.

s.gannon@uws.edu.au

\begin{abstract}
Where else can educational research begin and end, if not with the body of the researcher, if not with the particular material/corporeal/ affective assemblages that this body is and has been part of? This paper traces the mutual constitution of bodies, identities and landscapes through memory as the body of this educator travels through multiple scenes of geo-spatialtemporal movement, and down the east coast of Australia. This movement parallels the movement from being a school teacher to becoming an academic. Throughout the paper landscape is foregrounded, and the body in landscape is evoked through poetic and literary modes of writing around the themes of learning and losing. The body in landscape is not merely the body of the writer. Other bodies in the landscape include 'the curve of the snake' the row of protective hills that were said to protect her tropical home from cyclones - and the 'scene of the crocodile' - the rock that hung over the valley she passed on her way to school that she had learned of from Indigenous teachers. The political and ethical consequences of memory work, of body and place writing, and of genres of writing in educational research, are also considered. The paper argues for an embodied and reflexive literacy of place that incorporates multiple modes of knowing, being and writing.
\end{abstract}

Keywords: space, place, body writing, memory, identities, landscapes, education.

\section{Introduction: On writing}

Despite the confident tone of the abstract, this paper is haunted by a sense of loss, and its writing has been experienced as a series of tiny aporias, blocks, stoppages, impossibilities. Thus this paper is shaped more like a series of curves, a meandering, than the linear rational argument of academic convention. It is not that I eschew academic registers or modes of thinking but rather, this time, I want to incorporate the inchoate and erratic trajectories of desire, longing and, perhaps, of loss that are part of my stories of place. This means that in this paper I am taking up, and talking through, a different and more intimate register than is often the case in educational research contexts. In a sense, I am 'choosing and not choosing' as Frankham and Smears have recently put it, and I follow their preference with my own 'profane approach, concerned with indirection, [and] informed by the contaminations of literature' or, in this case, by a more literary and aesthetic mode of writing than is usually visible in educational research $(2012,362)$. This is a mode of writing that aims to move, in an affective sense, those who engage with the text as readers as well as the writer.

This paper follows a lineage of feminist writing interventions into academic conventions. Aware of feminist calls to write the body back and to unfix the fiction of objectivity in academic genres, I look for 'forms of writing that trouble the idea of "completion"', recognizing that 'nothing [I] say will have "captured" anything in a definitive way and neither will what [I] set out to understand "stand still" nor be complete' (Livholts 2012,1). My approach is also mindful of Braidotti's arguments that feminist researchers might 'start cultivating the art of disloyalty' through a 'healthy disrespect for both academic and intellectual traditions' (2011, loc 302, Kindle vs). This writing of place - of bodies 
located in place - is also, paradoxically, a 'dislocation' of genre in that 'creative, reflective and experimental writing methodologies' are still marginalized in academic discourse (Livholts 2012, 3). Richardson's earlier insistence that we approach writing as a 'method of inquiry' in itself in order to become tellers of 'local, partial, prismatic stories' about our lives and our work $(1997,3)$ underpins my inclination to shape this paper as a series of musings rather than a linear argument. I aim for a paper that is performative, affective and experiential, that is 'untimely' in attending to 'delay, dislocation and lateness', and that is emotionally and intellectually challenging to write (Livholts $2012,7)$. It aims to achieve the sorts of validity that Richardson describes as aesthetic and reflexive and where impact lies in its capacity to move emotionally or affectively (Richardson \& St Pierre 2005, 964), or to achieve what Lather calls 'voluptuous' validity (1994). Furthermore, in my attention to memories of place, I suggests that experiences of place are intertwined with trajectories of becoming and of identity. The paper is based on an understanding that memories of place in and out of formal educational contexts are valuable resources for the elaboration of pedagogical encounters and experiences of place learning beyond the most visible (Davies \& Gannon, 2009).

Specifically in educational research, subject increasingly to calls for transparency, clarity and reliability that erase the messiness of lived experience, it remains a radical step to write back bodies, affects and materiality into scenes of learning, and to foreground tentativeness and uncertainties. Thus the paper responds also to Lather's call for educational researchers to seek a 'disciplined messiness' that attends to 'language, bodies and material conditions' $(2010,10)$, and to Stronach's suggestion that, in educational research, it is narrative that 'empowers contradiction and lets history, ethics and desire back in' $(2010,172)$. Educational researchers investigating place-making practices have also taken up modes of writing that include narrative, theatrical, poetic and autoethnographic writing (Davies \& Gannon 2009; Gannon 2008, 2009, 2011; Somerville et al. 2011). Somerville has broadened research modes to include postcolonial cartographies, paintings and storylines of place amongst the Indigenous place-making literacies that continue to be marginalized in literacy discourses (2012a, 2012b). In this paper, I also reflect on the partial remapping of country that began when Indigenous narratives of place began to expand my understandings of the places I lived and worked.

Although all of the writers I have mentioned, as well as myriad others, have influenced my project, none of these has provided a map as to how to go about this project. Part of the difficulty of attempting to write otherwise is that, rather than the tidy and familiar shape of an academic argument, each paper must find its own shape and logic across a wider field of possibilities. Aesthetic and affective elements contribute to narrative and rhetorical structures. In a text of memory that samples scenes from various moments in a life, a chronological logic suggests itself but memory is not so neatly ordered. Rather, memories of varying intensities erupt and intermingle in the present, in the particular present ${ }^{12}$ where I write this paper. They cut across each other and different elements emerge and recede each time I come back to the writing. The text, perhaps like memory itself, moves. Particular figures, images or metaphors suggest themselves as axes around which to organise the text. The tropes of snake and crocodile that I planned to deploy in my exploration of changing subjectivities, allegiances and assemblages proved more elusive than I had anticipated and, in the writing, became overlaid with other figures. Storylines of 'learning' and 'losing' emerged through the writing, sliding between each other, suggesting that perhaps in my endeavours to attend to place in my life, that learning and losing have been interdependent and mutually contingent. Thus, through the writing, through my process of writing as an inquiry into place in this paper, my argument slipped towards a more reflexive and perhaps more complicated series of musings about the temporal and spatial cartographies of becoming.

\footnotetext{
${ }^{2}$ The paper shape-shifts through many moments of writing, as it develops through multiple drafts, each informed to varying degrees by reviewers and editors.
} 


\section{Prologue of place}

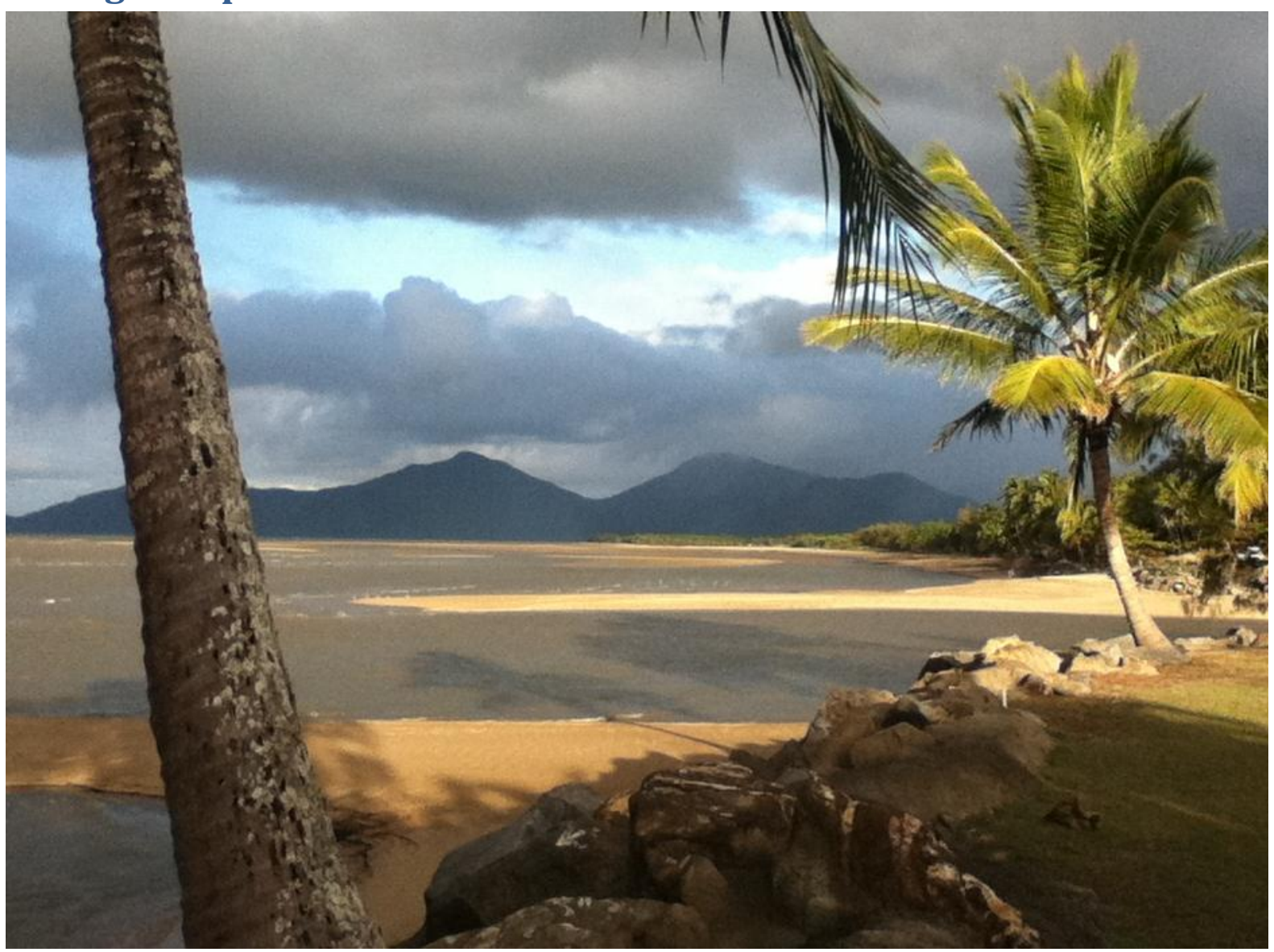

Treehouse (Machans Beach, QId, 1999).

No windows at all, upstairs

cavernous, moss green and smoke white

two rooms, up and down

what more could I need

beyond air sky light and moon

to cease my skittering

Along the seaward side

shutters on broomstick struts

eyelids open to the sky;

my sightline from bed: a desk, books

the scruffy nest of a Torres pigeon

in a coconut, paperbarks,

the moon, the northern drift

of sunrise in winter

When rain slants sideways

I push the bed across the room

drop shutters (lower their weight on my back,

knees bent, feet bare on wet tin roof)

\footnotetext{
${ }^{3}$ Versions of the poems in this paper can be found in my chapter in Poetic Inquiry: Vibrant voices in the social sciences (Gannon, 2009).
} 
When cyclones come I nest

under the stairs and pray

that this won't be

the kingtide collusion

that sends us under

This house is a talisman:

a house to be brave in, an embrace

a tower to shout from to a stranger

get out of my yard, l'll call the police

and do it; to say no, that's not what I want

any more and jump from the everyday into these

long days at my desk reading writing thinking

blue butterflies flash by, sunbirds hover

harvest cobwebs and spider's eggs, green frogs

leap from ledge to forearm to Foucault

and out again, without noticing

jasmine curling round the struts

impossible now - too late - to close them

\section{Learning home}

It is almost ten years since I left the lush environs of Cairns in North Queensland, Australia, the quirky little seaside suburb of Machans Beach where I made my home, and the creaky wooden house that came to feel like my second skin. It was there, upstairs along the open side of my bedroom facing the Coral Sea that I laboured, reading and writing and thinking my way towards a new academic self. There I spent the three years of my PhD, mostly at a wooden table against a wall that was barely there: a wall that ended at waist height and opened to the sky and the garden and the sea just beyond my garden. Sometimes, I lay in the bright woven hammock I had slung from the centre pole of the room to one corner. Here I read the books that were starting to turn around my ways of thinking and being in the world. These things had their own trajectories from other places into this room. The hammock evokes fragments of memory from the year when I left teaching to learn my way into other places far from home: of my trek to the village of the hammock makers outside Cartagena, Colombia; of my week sleeping and reading and swinging on a riverboat down the Rio Madera, Brazil; of another week slung under the roof of a roundhouse in a flooded forest in the warm rain outside Manaus. The elegant rosewood table that my computer sat upon had come somehow to a second hand shop in Cairns from Papua New Guinea. The orange sticker attached to its underside announced that it was 'Made by Baitabag Technical School, Yamba, Madang'. No memories of mine stick to it from then but there are hints of the forest from which the wood came, and the boys and the teachers who selected and pieced it together, who shaped and polished the rich red slab around which I arranged my new scholarly life.

My trajectory to this space of learning had been from high schools, those intense and vibrant spaces of mobile bodies and desires where I had made my professional life in North Queensland. I had moved away from classrooms, staffrooms, meetings, professional development sessions, the intensities of seven period days and kids milling around me at lunchtime towards this solitary scholarly habitus. There was minimal postgraduate research culture then at my regional university. My supervisor was far away on another campus. There was little electronic networking then. I drifted in to the university once or twice a week to use the printer in the shared office, or for the classes I had sporadically as a casual tutor, or to collect more books from the library. But my 
everyday routine was at home reading, writing, and thinking up in my eyrie entangled with the table, the texts, the air and the weather, the sunbirds hovering by the nests that hung from my eaves, the vines that reached around the wooden shutters, the green frogs that hopped along the roof and into the room, the snake wrapped around the balustrade who surprised me upstairs one afternoon, its raised head curiously to look at me, the screen and keyboard where I tapped tap tapped my way to a new scholarly subjectivity. Here my body shaped itself to the discipline of hours on end, still and quiet, focused on the texts that I was reading and writing.

The theme of learning place in North Queensland takes me back further, to the school where I taught almost a decade earlier. In the late $80 \mathrm{~s}$, at the school where I worked, the Djabugay language program that was taught at lunchtimes at the back of the library became integrated into the mainstream curriculum. For the next few years, all year 8 students did one term of LOTE ${ }^{4}$ language study (in Indonesian or German) and one term of Djabugay, the language of the rainforest Aboriginal people of the coastal hinterland of Cairns. The teachers were a Djabugay man named Roy Banning (or Wanyarra) and a Welsh anthropologist and linguist named Michael Quinn (or Gadja). Together they had worked with elders and linguists to document and prepare teaching and learning resources. This language revival project was focused initially on Djabugandji children, and the schools they attended. Our high school had approximately $10 \%$ of students who were Aboriginal, most of them from the Djabugay community of Kuranda. I had worked at an Aboriginal school in a different state, and had studied Aboriginal languages for a year at university. To begin with I sat cross-legged, kneeto-knee on the carpet in the library at lunchtime with the kids who came in with their pies on Thursdays. Together we learned words for bodies, things and particular places in the country that surrounded our school and our homes. We played language games, and learned the Storywater narratives and laws of the rainforest culture. When the program was formalised in the mainstream curriculum for year 8 , and later as an elective for year 9 and 10 students, I was one of several permanent teachers at the school who worked as assistants to Roy and Michael who spent one day a week teaching in the school with us.

We learned here of the mutual constitution of bodies, identities, spaces and places. We learned that there are no people without the land in its most specific detail. We learned that there could be no land without the ancestral figures who shaped the contours of the skyline, the water's edge and the intricacies of every waterway and mountain range and valley, every cave and crevice. Storylines of place, community, subjectivity, and spirituality are entangled in Indigenous literacy practices (Somerville, 2012 b). This was not my country, perhaps I didn't really have a country - just a few traces of belonging here and there as my parents moved us several times through my childhood, and as I roved through several more states as an adult. For the contemporary inheritors of the colonizers of a country like Australia, it is very difficult to flip dominant 'western' ways of knowing the country and embedding Indigenous language and knowledge into mainstream curriculum for all students, as the Djabugay language program did, is one way that this can begin. The specificity and intricacies of knowledge attached to local places and to particular peoples are often difficult to access. Yet it is clear that access to Indigenous literacies is urgent and necessary for an expanded and ethical literacy of place (Somerville, forthcoming b).

For the five or six years that I heard the stories again each term, teaching and learning from Michael and Roy alongside the children, through repetition, through chanting and singing and listening to the rhythms of games and songs and stories, through learning again and again and again with the children and with my teachers - there was a steady seepage of a new mode of thought and way of seeing into my senses. As they said in the introduction to their first resource book, Bulurru: Storywater, the stories 'speak the country, revealing it to be not a wilderness, but a humanized world, partaking of the spirit of the ancestors, their blood, their bones, their story, ever present in

\footnotetext{
${ }^{4}$ LOTE - Languages Other Than English. In Australia different high schools offer different languages and children tend to continue with the language they began at their primary schools. Year 8 is the first year of high school in Queensland.
} 
the land and in its creatures' (Quinn, McLeod, Banning, n.d., p. vi) ${ }^{5}$. No longer could I see the landscape of my locale without knowing that it had acquired form in more ways than I had been led to believe. When I walked along the beaches that stretched northwards from the city, near my home, I knew that contemporaneous with the end of the most recent glacial period, Damarri had led the people, the Bama, to heat rocks and put them along the edge of the rising sea to hold the water back and by so doing he had created this shoreline ${ }^{6}$. When I looked across to the south of the city, to the place that was called Walsh's Pyramid by the colonists, described variously as a granite core, or an extinct volcano, or a $922 \mathrm{~m}$ pyramid shaped hill, I also knew that it was created by the Storywater brothers, Damarri and Guyala, when they fought and the hot headed Damarri drew rock and fire from the ground to make a mountain ${ }^{7}$. I knew that on the northern side of the city, where I lived, the huge hanging rock by the Kuranda railway line above the Barron Gorge and the suburbs that sprawled towards it, called Glacier Rock on the map, was also Damarri. He had crawled up to the top of the ridge from the Redlynch valley, dragging behind him the bleeding stump of his leg, bitten off by the crocodile to whom he'd given wooden teeth $^{8}$. In the final school that I worked in, just before my PhD, I began and ended each day with the treacherous drive up and down the Kuranda Range road, with the rock that was Damarri coming in and out of sight, as I followed the curves of the road. This was knowledge that was not primarily cognitive, but also affectively and materially potent, and it was reshaping my sense of how the world is through a more immediate and unmediated knowing. Forty percent of the children at this school were Indigenous, as were many of the adults who worked at the school, and the Djabugay program had been relocated and continued here. Then I left.

\section{Losing}

What did I lose in my leaving? What did I leave? It seems trite to even draw attention to the fact that academics, though perhaps no more or less than many others who have fewer options and privileges, are a mobile workforce. It seems self-indulgent, old-fashioned, whining, to even suggest that my short move - within one country, within one profession (from teaching into teaching) - was in any way disruptive to my life. But it was. I moved alone. I knew just one other person in the city and she had moved to Singapore. I knew just one person in my new workplace, also new and on another campus. I didn't really know what it was I needed to teach. At the time each state had a distinct and entirely different curriculum and assessment framework for each secondary school subject and I knew nothing at all about the NSW English Syllabus that I was preparing pre-service teachers to teach, although I knew the Queensland one thoroughly. I didn't know how to live in the city, and chose not to, moving instead to a cottage in the lower Blue Mountains not far from my campus. Arriving in autumn, I found I didn't know how to live even in this mild winter, after more than twenty years in the tropics, particularly in a cold house on the wrong side of a ridge that never saw the sun. I lost the sense that this was my place, these were my people, even that the space that I draped my home life around fitted me. I didn't know the land here, the stories of the place, and I didn't know what stories I might make of myself in this place and space. In some ways, it seemed, I had lost my bearings.

I went back when I could for short bursts of warmth and belonging, over the next nine years, but these opportunities were fewer than I had imagined. Each time felt more alien as though I was no longer of this place, though at the same time little narratives of past moments and encounters arose for me at every turn, and the knowledge of place that had become part of my way of seeing stayed with me. But new waves of people had moved in, and left, and skylines had shifted, including my own. There were many there I knew and loved, but we had all learned to live without each other by

\footnotetext{
${ }^{5}$ Samples of the currently out-of-print teaching Djabugay teaching and learning resources can be found at $<$ www.djabugay.org.au> under 'Language books'.

6 'Djirru Damarri-nguu bana burrungany' or 'How Damarri stopped the waters' pp. 29-34, 58.

7 'Yaba mulu Bulurru' or 'The two Storywater brothers' pp. 9-15, 57.

8 'Djirri ganyarrangu dirra dugany' or 'How the crocodile got his teeth' pp. 17-28, 57-58.
} 
then. I kept my house for the first few years, renting it out to a friend while I suffered a string of evictions and end of lease removals in the lower mountains. The usual cycles of cyclones seemed to worsen and when cyclone Larry crossed the coast and destroyed Babinda, south of Cairns, it was time to let go.

Cyclones were another temporality that had marked my life in the tropical north. They brought another sort of body knowledge, a more haptic mode, inflected by the vagaries of air, temperature and climate. Extremes of wet season rains, of king tides, of wild winds and the summer threat of cyclones brought other ways of knowing the self in place. Cyclone Winifred (1986), soon after I moved there, caught me and my then partner, six others and a dog on a exposed beach at remote Cedar Bay and the worsening weather forced us to return in high seas in three open dinghies. But it missed our new home in Cairns. When Cyclone Joy (1990) looked like it would hit, I had already driven as far as Brisbane in an old green Kombi van on my way to a teaching exchange in another state, and was poised to turn around until we heard that Cairns had been spared. When Justin (1997) swept through, I pulled down the cyclone shutters upstairs and sat it out with a friend in a space we had made under the stairs in the middle of the house. We packed ourselves in with mattresses, a landline telephone and supplies of torches, water, food and wine. In the scariest moments, though mindful of the warnings not to use the telephone, we phoned our friend on the waterfront who was cowering in his bathroom hoping that his roof would hold. My old house leaned and breathed with the wind, soaked the rain up into its pores, and we leaned and breathed with it. When Cyclone Steve (1999) came, I called off my birthday party. As the city shut down, I locked the shutters and evacuated elsewhere. Afterwards, as usual, my suburb was flooded in and I longed to be in there with my neighbours and friends, eating the food from the thawing freezers in big communal barbeques, visiting each other to check out the damage and celebrate in our exhilaration that we had survived. An ancient frangipani, the height of my house, just outside my kitchen, had been pulled up by the roots and smashed across the fence and carport of the house next door. The back yard was a mess of branches, palm fronds, fallen coconuts and pawpaws but everything was fine. The old house was still standing, and I was a decade older and glad for the life I was living and the place where I was living it.

This is where my meanderings break down again. Someone said once, in the newspaper or on the radio, after one of those cyclones, a feng shui practitioner or an elder from the Cairns Chinese community, that the curve of low hills snaking around the horizon to the west of the city would always protect us from a dead hit by a cyclone. I find no traces of this figure when I return, no one remembers and there is no mention in the newspaper archives. Was it a fantasy figure, conjured somehow in my mind, turning a dream or a desire into a memory? I see it, persistently, in the corner of my eye, a long curving creature coiled loosely around the city. In my imaginary sightline it begins as far around as Cape Grafton, near the Yarrabah community in the east, folds itself around the other side of Trinity Bay to the back of the city, forming the range above Bayview Heights, Lake Morris, the Redlynch Valley, Kamerunga, Freshwater Creek, the Barron Gorge, stretching past Smithfield and the Macalister Range to the north. I try to track the curves of the body and match them to names on Google Earth but I'm confused by new names and uploaded photographs and videos that don't show quite what I remember. When I'm in Cairns I try to capture the sleeping creature of my memory in photographs from different vantage points at intersections, on the waterfront, on the beach and from out at sea but none quite capture what I want to think I know. What does this mean for what I claim about knowing landscape otherwise, when a phantom figure can populate memory with such insistence? I think it means I've left now, irrevocably, and everything I thought I knew is under erasure.

\section{Learning}

A walk in the park (Glenbrook, NSW, 2004). 
This house, dark and sharp

spits me out to morning and a walk

There's a curve in the steps on the way down

giant tree ferns spill from a cleft,

each seed and tiny flower and blush of new growth

Steps me through sandstone country

platforms and ridges jut out

weathered grey, lighter where the stone splits

and lichen surfaces

Down by the pools in the creek

the light breaks through and I'm close to the detail

the weirdness of banksia bottle brush grass tree

angophora shading through bone-white

salmon-pink grey -blue

bark strips hang down

I sit by the blue pool, tannin-brown

clean and cold, and wish that I could meditate but

I want to be aware of the kingfisher

and the insects buzzing in the reeds

and the quality of light changing on the stone shelf

on the other side of the creek

It means learning a new place. Even though I don't know the particulars in story and language of this landscape, I can track it with my feet, my skin, my eyes and ears, and let it talk to me in whatever colours and textures and senses emerge in the encounter. Given that I do not have the opportunity to learn language that came to me in the school where I was teaching in the north, it means I have an obligation to seek out what I can learn about Darug culture, language and land - down here in the Blue Mountains where I now live. It means listening to the land in any of the languages that it has.

The table from Madang and the hammock from Colombia, the books of Foucault and the others that have joined them have come with me to the mountains. I still set my computer on the rosewood table, and sometimes I sling my hammock from the verandah and read in the dry heat and shade of the southern summers. Here we form assemblages with elements of past and present, old places and new, trajectories of being and becoming, of home and of work, of desires entangled with the scholarly habitus that has extended well beyond the apprenticeship of the PhD I was working on ten years ago. The imperative to think and read and write that began as a joy has become a compulsion and weekends which could be for place-making through walking, through story, through language and the body are, too often, used for working. The disciplined body of the scholar curves at the shoulders, hunches over the screen and keyboard like the medievalists hunched over their texts in the scriptorium, the knot in the right shoulder blade feels as hard and permanent as any gnarled tree trunk and the tendons of the ankles shrink and scream in the mornings from this too sedentary life. Eyes peer through ever increasing magnifications. Beyond the glass of the windows in this study, past the blinds that keep the heat from leaking out in the winter, there is a world and this body is part of it. This is what I'm learning. 


\section{References}

Braidotti, R. (2011). Nomadic subjects: Embodiment and sexual difference in contemporary feminist theory (2nd edn). New York: Columbia University Press.

Davies, B. \& Gannon, S. (Eds.) (2009). Pedagogical Encounters. New York: Peter Lang.

Frankham, J. \& Smears, E. (2012). Choosing not choosing: the indirections of ethnography and educational research, Discourse: Studies in the Cultural Politics of Education, 33(3), 361-375

Gannon, S. (2008). Inhabiting silence: A sorry story. LEARNing landscapes, 3, 235-244. Available at: www.learnquebec.ca/en/content/learninglandscapes/index.html

Gannon, S. (2009). Writing poetry in/to place. In M. Prendergast, C. Leggo \& P. Sameshima (eds.) Poetic Inquiry: Vibrant voices in the Social Sciences. (pp. 209-218). Rotterdam: Sense Publishers.

Gannon S. (2011). Difference as ethical encounter, Cultural studies-Critical methodologies, 11(1), 71 $-75$

Gannon, S. (2011). Mapping Machans Beach: Meandering in place: (a beginning). In C. Camden Pratt, S. Hill and D. Wright (eds). Social Ecology: Applying Ecological Understandings to our Lives and our Planet. (257-266). Gloucestershire, UK: Hawthorn Press.

Lather, P. (1994). Fertile obsession: Validity after poststructuralism. In A. Gitlin (Ed.), Power and Method: Political activism and educational research (pp. 36-60). New York: Routledge.

Livholts, M. (2012). Introduction. Contemporary untimely post/academic writings - Transforming the shape of knowledge in feminist studies. In M. Livholts (ed) Emergent writing methodologies in feminist studies. (1-25) New York: Routledge.

Richardson, L. (1997). Fields of play: Constructing an academic life. New Brunswick: Rutgers University Press.

Richardson, L., \& St. Pierre, E. A. (2005). Writing: A method of inquiry. In N. K. Denzin \& Y. S. Lincoln (Eds.), The Sage Handbook of Qualitative Research (pp. 959-978). Thousand Oaks, CA: Sage.

Somerville, M., Davies, B., Power, K., Gannon, S., Carteret, P. (2011). Place Pedagogy Change. Rotterdam: Sense Publishers.

Somerville, M. (2012a). Water in a dry land: place learning through art and story. New York: Routledge.

Somerville, M. (2012b). Place, story lines, and the social practices of literacy. Literacy.

Wyatt, J., Gale, K., Gannon, S. \& Davies, B. (2010). Deleuze and collaborative writing: An immanent plane of composition. New York: Peter Lang Book. 